УДК 392.8(540.13):130.2

DOI 10.32340/2414-9101-2020-2-7-17

\author{
P. Gupta, \\ Dr. of Biological Sciences, \\ Himachal Pradesh University (Shimla, India) ${ }^{1}$ \\ pankajgupta08091975@gmail.com
}

\title{
FEAST OF FLAVOR: \\ CULINARY AND GASTRONOMIC TRADITIONS OF HIMACHAL PRADESH, INDIA ${ }^{2}$
}

\begin{abstract}
Cultures with a stable history have food habits and traditions compatible with survival of the group in particular settings. Food consumption patterns intersect with economics, politics, social structure, and culture, and thus analysis of these is imkhud perative. The culinary traditions of Himachal (a North state of the Republic of India) are as prosperous and assorted as its communities. This traditions, which are the integral part of culture, are an art which has been passed on from one generation to another entirely by a word of mouth. Food is a subtle insignia of unification of global and local. The knowledge of how cuisines acclimatize to new environments gives a valuable counterbalance to think of the olden times in terms of impersonal, conventional, and tempting influences ${ }^{3}$.

Keywords: food habits, nutritional traditions, a national cuisine, ethnic food consumption patterns, traditional food cultures, Himachal Pradesh (the Indian state), Kinnaur (district in the Indian state of Himachal Pradesh), Spiti-Lahaul (district in the Indian state of Himachal Pradesh), Kangra (district in the Indian state of Himachal Pradesh), Bilaspur (district in the Indian state of Himachal Pradesh), ethnic traditions of cooking, gastronomical culture of ethnic communities, cultural patterning of nutrition ${ }^{4}$.
\end{abstract}

INTRODUCTION. Food plays a pivotal role in meeting the nutritional requirements of the body and maintenance of good health. The presence of essential nutrients in the food determines the growth, health and efficiency of an individual and plays a vital role in physical and mental well-being of individuals as well as of nations [1]. Health has always been a major concern of community development. It is indispensable for a balanced development of individual within the family and as a part of community and

\footnotetext{
${ }^{1}$ Рус.: Панкадж Гупта, доктор биологических наук (Университет штата Химачал-Прадеш (г. Шимла, Индия)).

2 Рус.: Праздник вкуса: кулинария и гастрономические традиции индийского штата Химачал-Прадеш.

${ }^{3}$ Рус.: Аннотация. Для зрелых национальных культур характерны развитые системы обычаев и традиций, регулирующих процедуру приём пищи, которые сформировались в жёсткой зависимости от специфики условий жизни тех или иных этнических сообществ. Процесс оформления и закрепления коллективных поведенческих моделей этноса в области потребления продуктов питания протекает под доминирующим влиянием комплекса экономических, политических и культурных факторов, характера социальной иерархии. Разнообразие кулинарных традиций населения одного из северных штатов Республики Индия - Химачал-Прадеш - пропорционально пестроте этнического состава региона. Гастрономические традиции народа - неотъемлемая часть его культуры, они передаются из поколения в поколение исключительно устным путём. Современная национальная кухня - один из индикаторов, по состоянию которого можно судить о характере взаимовлияния глобального и локального в этнической культуре. Наблюдение за характером адаптации национальных кулинарных традиций к условиям современности даёт исследователям повод усомниться в том, что в стародавние времена инокультурные заимствования в этой сфере носили безличный и добровольный характер.

${ }^{4}$ Рус.: Ключевые слова: пищевые привычки, традиции питания, национальная кухня, этнические модели потребления продуктов питания, традиционные аспекты культуры питания в национальных культурах, Химачал-Прадеш (индийский штат), Киннаур (административный округ в индийском штате Химачал-Прадеш), Лахул и Спити (административный округ в индийском штате Химачал-Прадеш), Биласпур (административный округ в индийском штате ХимачалПрадеш), национальные традиции приготовления пищи, гастрономическая культура этнических сообществ, этнокультурные модели питания.
} 
nation. World Health Organization defines health as a state of complete physical, mental and social wellbeing and not merely the absence of disease or infirmity. In the recent years, this statement has been modified to include the ability to lead a 'socially and economically productive life'. Any national cuisine is an aggregate of local diversity of its cuisines, which are the cultural and historic pointers of their respective provinces. India is home to numerous regional cuisines that showcase its culinary diversity [2]. Cooking is a unique human trait which includes an assortment of food processing techniques [3]. While cuisine is a systematized sequence of food preparation techniques intended to present scrumptious and nutritious food. India has a distinct blend of ethnically and climatically assorted regional cuisines. Its culinary history dates back to the early Indus valley civilization [4]. The food consumption patterns in India are deep-rooted in perceptions of evading disease and promotion of health.

In human beings, the food perception including olfactory and gustatory mechanisms is the main stimulus for food liking. These preferences are governed by diverse factors for instance, culture, weather, topography and heredities, leading to the advent of local cuisines [5, 6]. Food has acted as destination, venue, and vehicle for tourism. As destination, it is mostly an experience. The preparation, consumption, and even viewing a dish give a sense of exotic exclusivity. As vehicle, food offers an entrance point for looking at another culture. As venue, it offers a site from where a culture can be reviewed. These aspects can be commercial or domestic, public or private, festive or ordinary and offer a substantial, inevitable base from which other facets of culture, history, religion, artistic traditions, customs, etc. can be understood and experienced. According to Long [7], food is a significant means to peep into the culture of the particular region since: "....it allows an individual to experience the 'Other' on a sensory level, and not just an intellectual one..."

The nutritional significance of traditional foods needs to be accepted and popularized. Ethnic foods are socially, culturally, and economically important. Ethnic food plays a vital role in confirming food security and embraces a tremendous potential in combating undernourishment. It is essential that the wisdom of their preparation is not lost. The knowledge on traditional food must be extended. Food consumption patterns can be made a basis for comparing different societies and analyzing the patterns of change. According to Mead [8]: Food consumption patterns or food habits are the ways in which individuals or group of persons, in response to sociocultural pressures choose, consume and make use of available foods.

The folklore and superstition of cultures throughout the history have attributed curative or toxic properties of edibles. This preference has not disappeared even with the advent of the science of nutrition and medicine. Even today, the food folklore lasts, although in many cases it is paradoxical with scientific validation. Food trend is a dietary practice based on an inflated belief in the effect of food or nutrition on health. From prehistoric times, there has been significant socializing of cultures and gastronomies within a region. Food and eating habits of different ages and cultures have always captivated anthropologists, readers and researchers. The universality of food gives it vast prospective as an indicator of cultural and historical metamorphosis. Each society produces and distributes food and has its own way of doing so. Food besides acting as a physical need, acts as a best ground for articulating creativity and epitome of cultural and personal individuality. An attempt has been made in the present paper to present the culinary and gastronomic traditions of Himachal Pradesh.

METHODOLOGY. The data for the present study was gathered by using a pre-designed questionnaire which was administered on elderly women and traditional chefs involved in the preparation of ethnic foods in different parts of state.

RESULTS AND DISCUSSION. Himachal Pradesh, has so long, been of interest to the biologists, anthropologists, sociologists and economists on account of its peculiar ethnicity and socio-cultural features. All societies evolve and elaborate rules about the preparation and consumption of food, guidelines that reveal internal structure; and actually no region has been so poor as not to have special foods for festivals or family occasions. Traditional food cultures have developed over thousands of years and have been tested, refined, creating a repertory of foods and preparing techniques, capable of sustaining life in specific environment. What is to be consumed as food varies with culture and society; and what is eaten, how it is prepared, how it is served, who eats it, needs to be analyzed as this help in understanding about the functioning of societies. Narratives of culinary traditions look into the dispersal of plants and animals, farming systems, food preferences and taboos governed by religion, specific food types, methods of cooking and serving, which were spread by the explorers, immigrants, and traders from one region to another. Certain foods are found associated with particular groups and it has been common to associate 
the foods of that region with its climate and terrain and sometimes used as basis for description of character of its people.

The common beliefs, customs, practices related to health and disease in turn influence the health seeking behavior of the community. Communities of Himachal have retained their age-old customs and traditions, and are proud of their affluent cultural heritage. However, to keep pace with the changing times they have even embraced the influences of contemporary world. Their zeal for life is reflected in their colorful attire and incredible festivity. The land reflects unity in diversity and is the meeting ground of different religions, ethnicity and cultures. The beauty of its culture lies in its simplicity and hospitality which is full of humility. The culture of Himachal is incomplete without the mention of its delicious cuisine. The availability of food in inaccessible mountainous regions depends on the climatic conditions which in turn affect the agriculture, horticulture and other natural resources such as wood, water, soil, etc., and consequently life of the people. Since the people in Himachal practice both agriculture and horticulture, the two act as good source of food and income. Though the state manifest diverse agro-climatic conditions but different types of crops are grown, which vary from cereals, pulses, oil seeds, root crops, and vegetables to subtropical fruits, viz. mango, citrus fruits, litchi, grapes, etc. temperate fruits like apple, pear, apricot, peach etc. and nut crops like walnut, almond, etc. The seasonal cash crops are not enough to meet the whole year demands of people and many crops cannot be grown in a particular area, hence people depend on local market for buying food items besides getting them from their own fields. The domesticated animals' include cow, sheep, goat and buffaloes and the purpose is to obtain wool, milk and meat. A number of wild fruits, vegetables and mushrooms are collected and consumed by people, for instance, Jungli Chulai (Amaranthus), Ramban (Sentry Plant), Churro (Royal's Spurge), Kathi (Indigo), Karyalo (Orchid Tree), Chuch (Watercress), Lingru (Vegetable Fern), Dhaeu (Monkey Fruit), Kawarpatha (Indian Aloe), Gucchi (Common Morel), etc. Some of these are consumed seasonally and some throughout the year for their special taste, medicinal value and for a change. The incidence of extreme weather events, such as storms, floods and avalanches affect the local food and nutrition situation and consequently the access to food. Hence, the people have developed mechanisms to cope up with the adverse conditions. The food is selected keeping in view its nutritive value, 'hot' and 'cold' nature and medicinal value. In addition to this, people have developed indigenous methods of food storage, preservation and food consumption.

The variety of cooking is a reflection of the myriad nutritional, aesthetic, agricultural, socioeconomic, cultural and religious considerations that impact upon it. Most traditions have an identifiable cuisine, a definite set of gastronomic traditions, references, and practices. While some food can be eaten without preparation, many foods undergo some form of preparation for reasons of safety, palatability, or flavor. The term 'cooking' covers a vast range of techniques, tools and combinations of ingredients to improve the flavor or digestibility of food. It mostly requires the selection, quantification and mixing of the ingredients in a systematic manner to achieve the desired outcome. It may also involve mixing, heating or cooling, pressure cooking, fermentation, or combination with other food [1]. In India, consumption of fermented food and beverages using local food crops and other biological resources is very common, especially among the highlanders of Himalay, though the name of the products and the base material vary from region to region. The people of Indian trans-Himalayan region such as Ladakh and LahaulSpiti make local beverages called chaang.

The food within the state of Himachal also varies from one region to another. The food is simple and made delicious with addition of clarified butter. Maize and buttermilk are mainly consumed almost throughout the state. Non-vegetarian food is also common in Himachal. The average kitchen in the state uses a variety of meat, pulses and cereal preparations. However, there may be local variations, for instance, in the cold deserts of Kinnaur and Lahaul-Spiti there is more emphasis on locally grown coarse grains like buckwheat, millets and barley. In areas with pastoral traditions, milk and dairy products are used profusely. While the everyday meal is the usual dal-chawal (lentil and rice), subzi-roti (vegetable and bread), while special dishes are cooked during festive occasions. Dham, a traditional festive meal is cooked only by bottis, the traditional chefs and is served on leaf plates. The typical menu for a dhaam consists of rice, madra of red kidney beans, chickpeas, cooked in yogurt, black gram lentils, khatta, a sour dish and mittha, a sweet dish, though meat preparations are also common.

Cuisine in Himachal is as diverse as its culture. Its flavor and aroma varies from community to community but a typical Himachal's cuisine is characterized by a variety of spices and cooking techniques. Spices are dry roasted before grinding for a few seconds to improve the flavor. Spices are used as flavoring agents or as seasoning both in fresh and dried form in almost entire Himachal. Many of these 
are grown in the locality. Along with spices, some dry fruits, dried mango powder, pomegranate seeds, seeds of cucumber, watermelon, sesame, muskmelon, poppy, mustard and hemp, curry leaves, etc. are used while preparing the ethnic foods. The spice paste is cooked until the oil runs clear to give full flavor. Gravy of various curries is thickened by adding gram flour or maize flour along with spice pastes, yoghurt and tomatoes. Turmeric and edible colors are often used to embellish the delicacy. The use of black cumin seeds, curry leaves, cloves and Indian bay leaf is common. Traditionally the food is cooked using various methods to impart different tastes and appearances. Different permutations and combinations are used for preparing food so as to have diverse range of foods. Yogurt or buttermilk is used in number of dishes. Madara, a special curry of Himachal is usually cooked in yogurt. Adding yogurt not only imparts a unique taste to the dish but also improves its nutritive value. Food is cooked by the application of heat, which may be either moist or dry and there are numerous ways employed for cooking food in these areas. There is variety of steamed, boiled and even roasted foods.

Fermentation is yet another important method employed in cooking food. Fermented foods are prepared by the action of microorganisms but the process involves natural fermentation. The microorganisms alter the properties of the food, for instance, yogurt or bread. The purpose is often to get a better taste or texture and the food becomes more digestible. A number of ethnic foods and beverages are prepared by using fermentation. These include baturus, siddus, khobli, arsay, khatti wadies, chiltas, etc. For making baturus, dough of wheat flour is allowed to ferment for 6-12 hours and then balls prepared from dough are given round shape, followed by deep frying of the same. In case of siddus and khobli, the basic ingredient is wheat or barley flour and using a starter, its dough is allowed to ferment for 6-12 hours. Once the fermentation is thorough, a stuffing is prepared and filled in. There is a large variation in the ingredients to be used for stuffing, for instance, grinded black gram, linseed, walnut, sesame seeds, poppy seeds, animal fat, etc. along with salt and spices. These ingredients are either used in combination or separately. Once the fermentation and stuffing is done, the next step is cooking which involve steaming. The steaming is done in a traditional way.

Another most preferred gastronomic item of Himachal is dried meat. Meat is dried for winters. In district Kinnaur \& Shimla, a special occasion is marked for slaughtering of goats. The meat is thin sliced and tied on strings and allowed to dry. In tribal sub-divisions of Pangi and Bharmour of district Chamba, the meat is smoked-dried to prevent its spoilage. In low-lying areas of Bilaspur, Hamirpur, Mandi and Chamba, traditional preservatives such as salt, turmeric, etc., are used for preventing its spoilage. The dried meat, when cooked tastes delicious. Likewise, in some areas of district Shimla, Kinnaur, Chamba and Lahaul-Spiti, charbi or animal fat of slaughtered sheep and goat is extracted, dried and stored for long-term use. The animal to be slaughtered for extraction of fat is suitably fed for few months and after slaying the animal, the fat is taken out, kept covered with dry flour and stored for months together without using any preservative. The fat so extracted is used in number of recipes and even relished as stuffing in certain traditional foods.

Churra, a local variety of cheese is prepared and consumed in district Kinnaur and Lahaul-Spiti. Milk is curdled and sieved using a muslin cloth to drain out excess of water. The same is hung for 5-7 hours to extract water. The remaining solid mass is dried and made available for consumption. By using this method milk can be stored for longer duration and used in the hostile weather conditions. In lowlying areas, similar type of semi-solid cheese is prepared by using buttermilk. The buttermilk is treated in a similar manner and water is drained out. The remaining semi-solid mass is stored in earthen vessel for long-term use and whenever required the semi-solid mass is dissolved in the water to prepare the buttermilk. Thus, the buttermilk can be made available even during the winters. Yak butter is another ingredient which is used in preparing number of delicacies in cold deserts of state. Yak milk is allowed to ferment overnight and resulting yogurt-like stuff is churned for about an hour until butter forms. Yak butter can last for up to a year and is usually preserved in number of ways.

Morels, locally called gucchi is one of the wild edible fungi found in Himachal, which is collected from the forests for its high market value. Rural communities collect and sell the wild edibles in the local market, besides keeping some for their own consumption. A number of dishes are prepared by using morels as one of the ingredients, for instance, gucchi baath (rice cooked with morels), gucchi ka madhara (morel curry) etc. Besides this, a variety of alcoholic and non-alcoholic beverages are consumed in Himachal. In Kinnaur, local wine is prepared from grapes, wild apricot, pears, apples, wild almonds, etc. Besides this, barley, rice, buckwheat is also used for preparing local wine. The alcoholic beverage pre- 
pared from grapes is named as angoori, the one prepared from wild apricot is known as chulli, the one prepared from buckwheat is known as rangphasur, the one prepared from rice or barley is named as chang and the one prepared by using mixed fruits is named as ghanti or ark. Jhol or lugri are the traditional alcoholic beverages prepared by people in district Chamba from rice. In Bharmour, alcoholic beverage called Sur is prepared from Kodo millet and Wallich milk parsley. Local wine is also offered to Gods during the religious festivals and is distributed as holy water. Chaang, an indigenous alcoholic drink is common during the marriages and other local festivals in Lahaul-Spiti. It is an essential welcome beverage and is believe to provide protection against extreme weather conditions. These alcoholic beverages are prepared in tanks made of wood, metal or plastic. While preparing these alcoholic beverages, vessels are tightly closed with lids to allow fermentation. Sometimes, the mixture is allowed to ferment for a specific period depending on the nature of beverage to be prepared. Fermented mixture is then filtered and its quality is best judged from its taste, aroma and strength.

In addition to this salt/butter tea is another heady drink of milk, yak butter, salt and an infusion prepared from plants available in Kinnaur and Lahaul-Spiti districts. People in Kinnaur prefer using the bark of Himalayan yew which is roasted and grinded before boiling in water. This tea is believed protect against cough and malaise. Salt/butter tea is prepared by blending butter, milk and salt in traditional vessels called dongbo.

Maize is the staple diet of people living in the Shivaliks and mid-Himalay, boiled rice and pulses are also the preferred food of the people. Rice is among the most valued grain and is used to propitiate the deities during the worship. The first produce of every season is offered to the village deity. Even the dhaam starts with boiled rice. Likewise, on the occasion of Minjar, a festival of Chamba, ear or spike of corn is worshipped to propitiate Varun devta, the Rain God and later exchanged among the relatives. People prefer taking meals thrice a day, viz., nohari or kalar, the breakfast, dopahri or dhiyan, the lunch biyali, the dinner, which is taken after sunset. Maize flour bread baked in traditional hearths, and lentil is served as the main course, which at times is supplemented with rice. There is variation in the variety of ethnic food, ingredients, manner in which it is cooked and served, and the same is governed by the geo-cultural setup of the region. In addition to the regular pulses, cereals and vegetables, people make use of leaves, flowers, stem, fruits and roots of wild edibles. Kinnaur and Spiti-Lahaul are relatively dry and people use locally cultivated grains like, buckwheat, barley and millets to prepare ethnic dishes like siddu, aktori, chiltu, etc. In the Southern region, the milk and milk products are used normally. The use of yogurt or buttermilk in most curries along with buttermilk is very common. In Kangra, for instance, the main ethnic foods are barah ke chutney, seera, chhacha, tremble ke sabji, phafru ka sag, lingru ki sabji, lasude ki sabji, ambua, etc. There is a wide range of variability in ethnic foods prepared from cereals, pulses, milk, etc. Some common food items include - bhaturu, babru, beduan roti, mitlidu, madra, sepubari, kadi, etc. The typical staple food of Bilaspur is wheat, maize and rice, which are cultivated locally. Mostly people are non-vegetarian and relish chicken. Additionally, the consumption of alcoholic drinks is quite common among people. One of the main features of the cuisine is its diverse range of dishes. Traditional cooking focuses on the preparations with whole wheat, maize, rice and other ingredients flavored with masala. The food is ideal for the lifestyle because the rural folk burn most of calories while working hard in the fields. The ingredients consist of onion, garlic and ginger. A few wild edibles are collected and consumed by people. Some of these are consumed seasonally and some throughout the year for their special taste, medicinal value and for a change. Some of the traditional foods include meat, babru, patandey, manday, mahani, kheru, sarson ka saag, dahi, lassi, etc.

Yoghurt is also an essential item of meal. The most common meal is kanak di roti (unleavened wheat bread) along with dal (curried lentils) potatoes or any other vegetable. People are fond of sweets. They prepare halwa, which is also offered as parsad in the temples.

Laddoo, or even raw sugar or gur, shakker and jalebi are also relished. In earlier days, chakki (a stone mill) kundi-sotha (pestle and mortar) were the main kitchen utensils, which demanded hard work. Earlier in a typical village house, one can find a chulla (hearth), chajj (a tray), chakku (basket), gaggar or ghara (earthen water pitcher). However, modern gadgets have replaced these. People of Mandi have a special liking for like bhaturu, kachori, sepubari, badana, khatti bari, bhalle, seera, etc. which are prepared from cereals and legumes. Bhaturu, chilru and kachori/ beduan roti is the staple food in rural areas of Mandi district. Some food items like kachori, ghayor, sagot, badana, sepubadi, moong bari, urad bari, khatti bari, dandal bari, seera, etc. are even sold in the market. 


\section{Traditional Utensils of Himachal Pradesh}

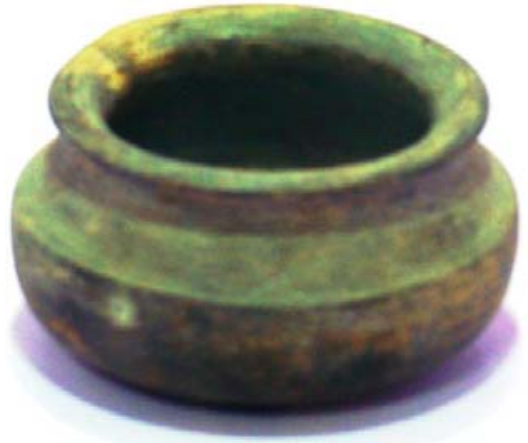

Wooden Pitcher

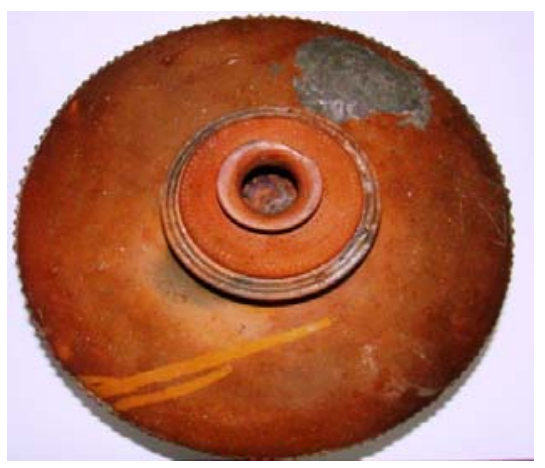

Earthen Pot

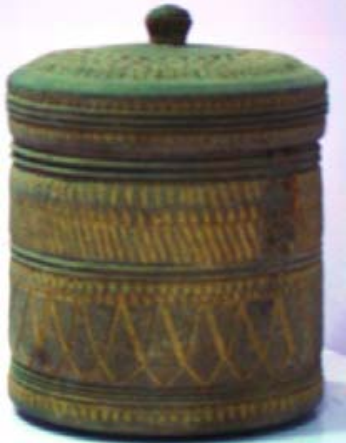

Wooden

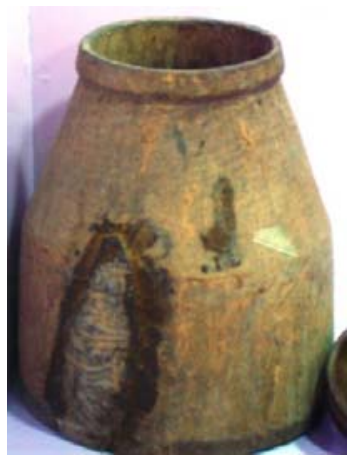

Wooden vessel

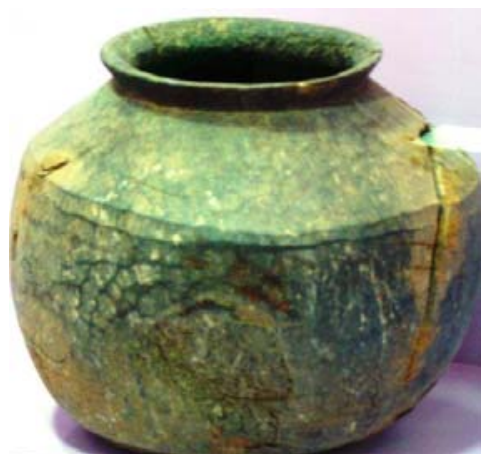

Wooden Pitcher

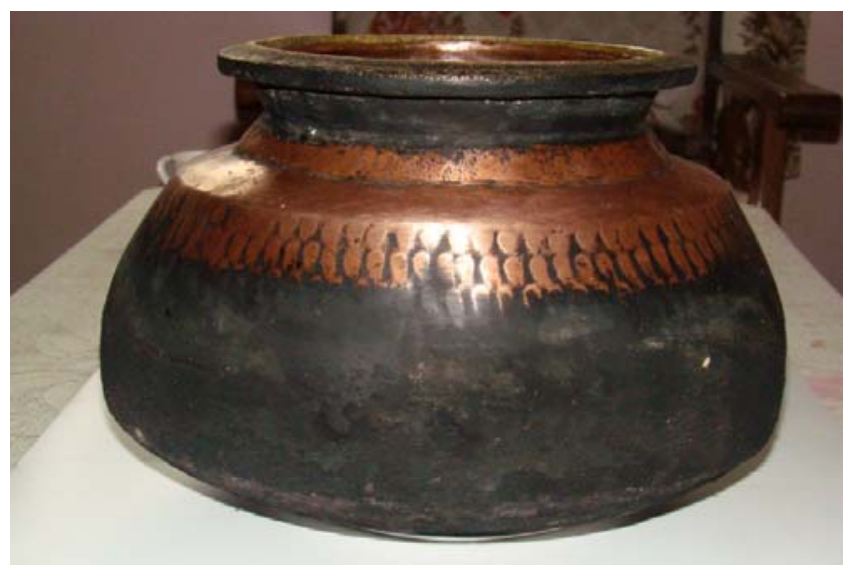

Copper vessel

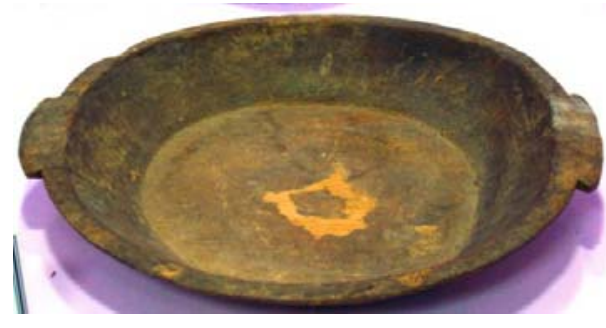

\section{Wooden Platter}

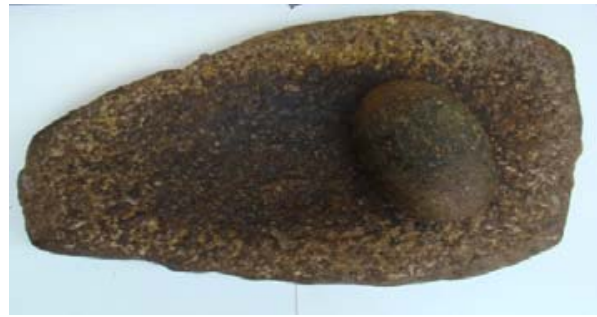

Stone slab for grinding

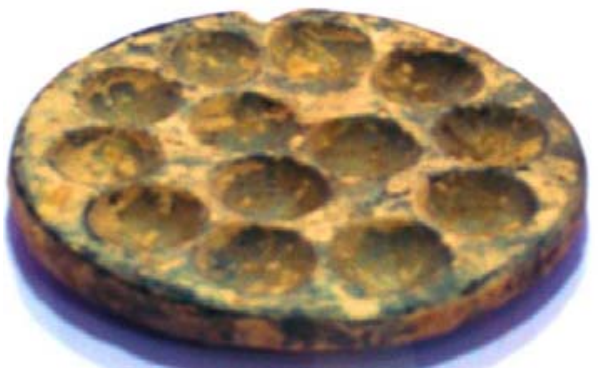

Stone casing for cooking food

People have developed traditional methods of food storage, preservation and food consumption, for instance traditional utensils are still used by the people in Kinnaur, but to a lesser extent. The traditional utensils mainly the stone vessel, serving spoon, wooden water storage tank, bronze vessel, plate, tea cup, stirrer, sieve, churning vessel, stone slab, hand mill, etc. which were used in the past are gradually been replaced by ceramics, plastic and metallic vessels. Isolated mountain communities with limited access to outside foodstuffs, used to grow traditional food grains, which constituted their staple diet. They used to cultivate wheat, com and traditional grains but no rice. Traditional cereals comprised of buckwheat, barley and amaranths. Peas and red kidney beans figured highly in their diet. Potatoes, pumpkin, turnip, etc. are few vegetables which are grown and consumed along with dry cheese. Meat was consumed mainly during winters. Apart from the staple food, which includes buckwheat, amaranths, and barley, people eat 
local coarse grains. Better road networks have confirmed the infiltration of rice and wheat in the food habits of cold desert areas. People in the cold desert areas prefer non-vegetarian food and relish goat or ram meat. The food consumption pattern in the area is under transition because of the wiping out of traditional food consumption patterns which is the result of changing cropping pattern in the area.

Cultivation of traditional crops has decreased. Traditional food of Lahaul-Spiti includes: chilra prepared by using natural inoculum and jhan chang, an alcoholic beverage. Chilra is chosen for its easy digestibility, better taste, flavor and dietary benefits, while jhan chang is preferred for its intoxicating importance and flavor. Wheat, barley, maize, buckwheat, rice and kodo millets are used for preparing routine and festive foods. Most of the cereal /legume based foods are prepared from rice, wheat and barley.

\section{Ethnic Food of Himachal Pradesh}

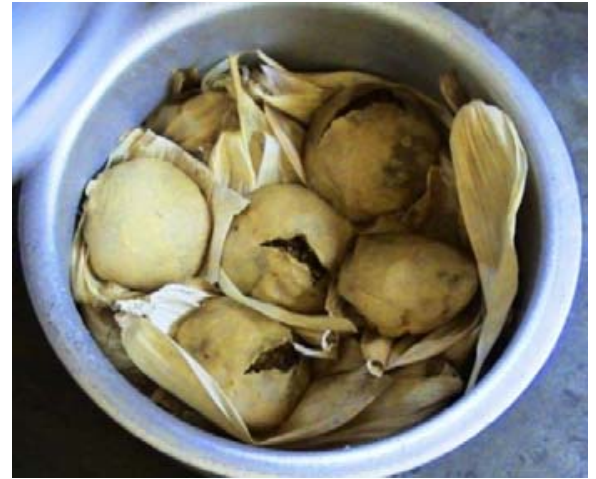

Siddu, ethnic stuffed bread
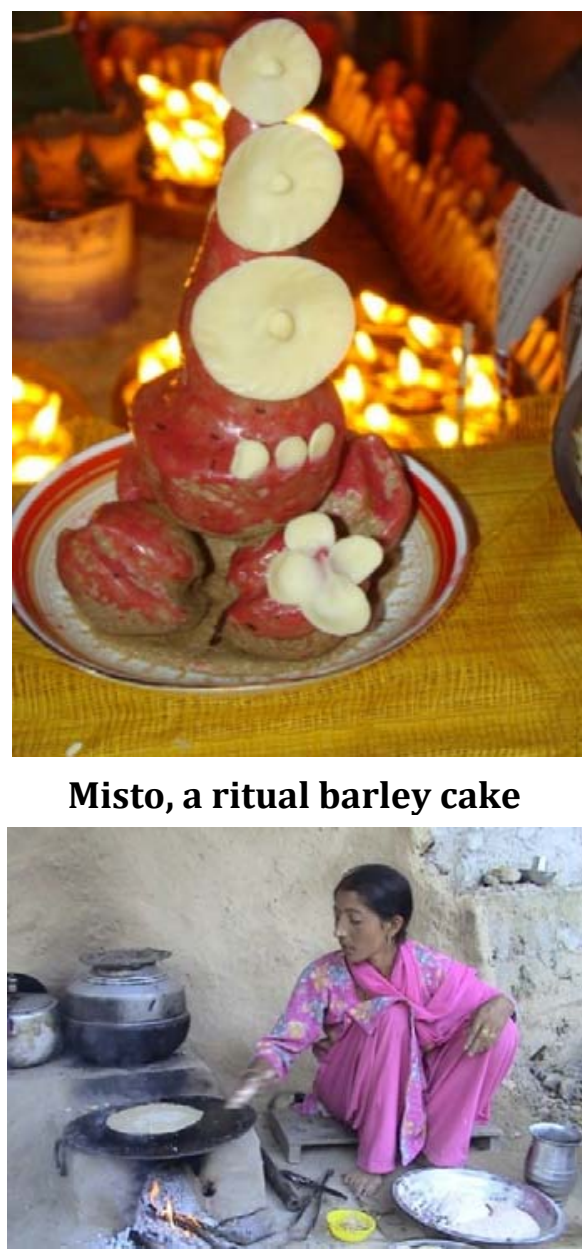

Preparation of Patande, the pancakes

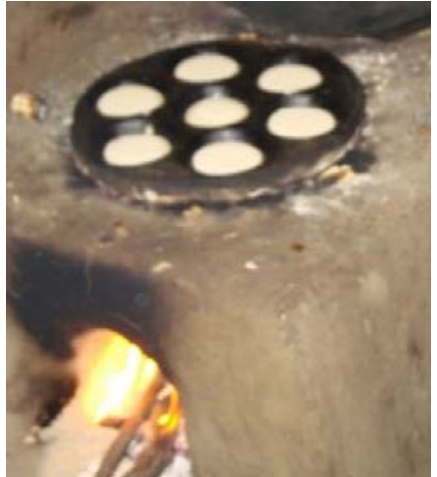

Ankelu, an ethnic

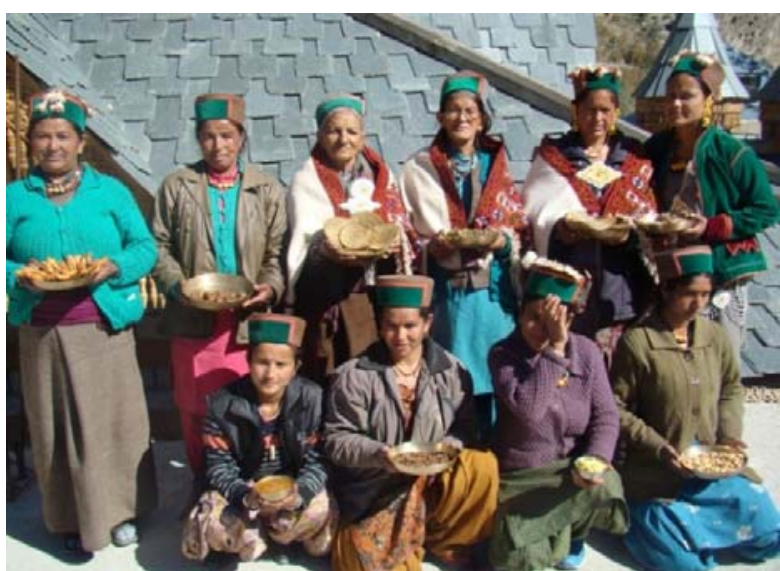

Women ready to serve ethnic food

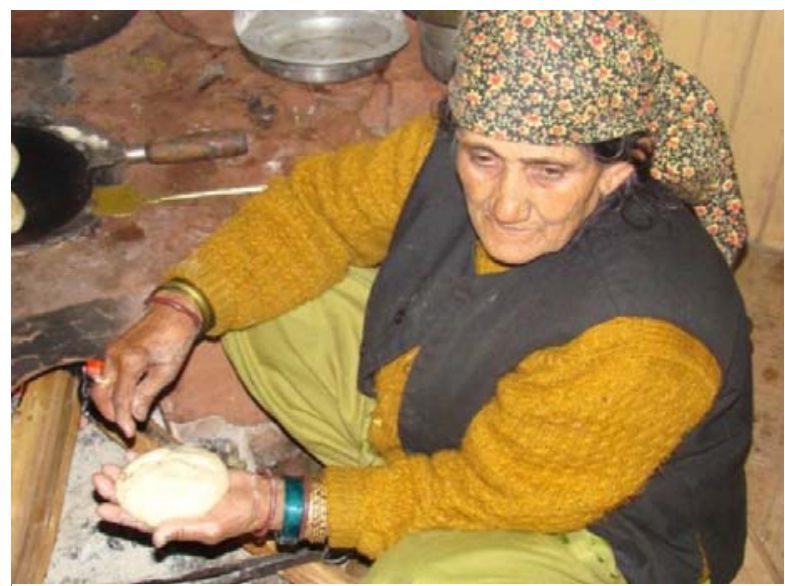

Preparation of Siddu, the stuffed bread 
These foods form a part of staple diet in form of unleavened bread, pancakes, curries, stuffed unleavened bread, and deep-fried unleavened bread in Lahaul-Spiti, Kinnaur, Chamba, Shimla, Mandi, Kangra and Kullu. These may be prepared from dough or batter, which may be fermented or nonfermented.

Traditional milk-based food stuff includes use of lassi (buttermilk); dahi (curd); jhol/ kheeru/ rehru, a preparation of buttermilk with spices and salted tea, common in Kinnaur and Lahaul-Spiti. In addition to this, traditional pickles, jams and chutneys of vegetables and fruits are prepared, for instance, Chamba Chukh, a unique mashed chilly pickle of district Chamba is famous throughout the state.

Likewise the pickles of ferns, bamboo, citrus lemon and mango, etc. are common. Besides this, the ethnic food in Himachal includes:

- Aktori, a festive dish of Lahau 1-Spiti, prepared in the form of pancake by using wheat flour and buckwheat leaves during the marriages;

- Anekelu/ Askalu, a steamed food, prepared from rice flour batter on festive occasion is common in some parts of Shimla, Solan and Sirmaur district;

- Auriya Kaddu or Amla Kaddu is common in Kangra, Mandi, and Hamirpur. In this, pumpkin is cooked in spicy gravy of amchoor, dried raw mango powder along with other spices;

- Ayet, the thin pancakes are cooked during the wedding ceremony in Lahaul-Spiti;

- Baabru, are the thick deep fried pancakes of wheat common in Mandi, Bilaspur, Hamirpur and Solan;

- Baddi, sun-dried chunks of grinded paste of black gram and ash gourd are common in Mandi, Bilaspur, Shimla, Solan and Hamirpur;

- Barri is a thick pudding of wheat flour common in parts of Shimla, Sirmour and Kullu district. It is usually served with clarified butter;

- Baturus are deep-fried fermented unleavened bread, common in Mandi, Bilaspur, Solan and Kullu;

- Bedi, deep fried fermented, stuffed unleavened bread common in parts of Mandi, Bilaspur, and Solan;

- Bhalle, deep fried disc prepared by using black lentil are served in parts of Bilaspur, Mandi, Kangra, Hamirpur and Shimla;

- Bugpinni/sattu/ doo, uncooked dough roasted and grinded barley grains served in Lahaul-Spiti and Kinnaur;

- Changapa, dough of roasted barley flour prepared in buttermilk on the auspicious occasion in Lahaul-Spiti;

- Chha Gosht, meat cooked in yogurt / buttermilk, is common in Chamba. In this marinated lamb is cooked in the gravy of gram flour and yogurt along with spices like, cardamom, red chilies, coriander, bay leaf, asafoetida, and paste of ginger and garlic;

- Chiltu/ hoda, pancakes of fermented buckwheat batter are among the staple food of Lahaul-Spiti, Kinnaur and Shimla;

- Gulgule, deep-fried fermented sweet fritters

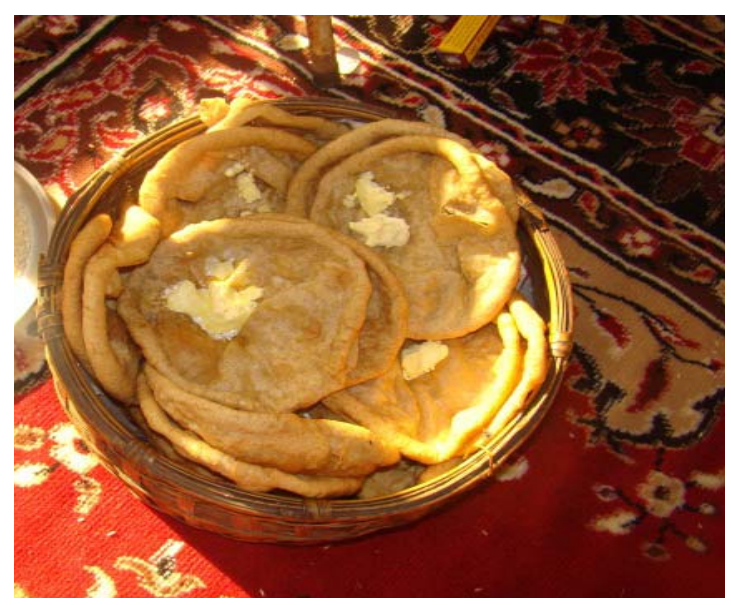

Poltu, deep-fried bread

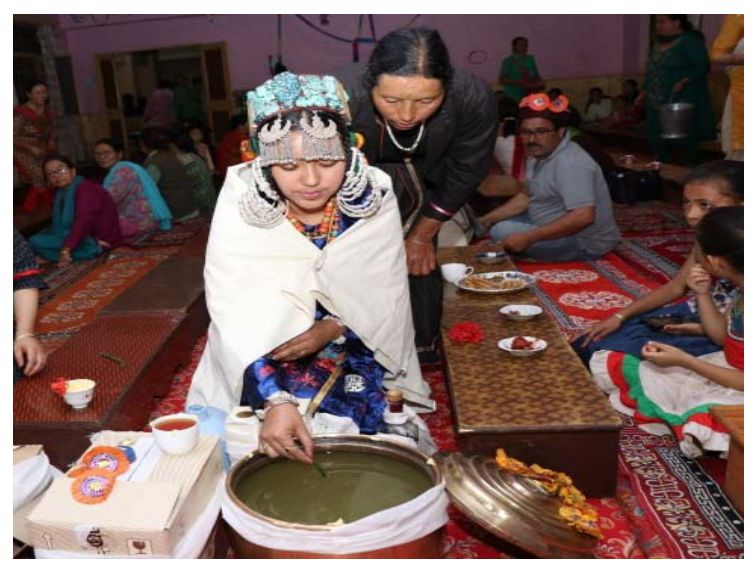

\section{Serving Chang (rice brew) in Spiti}

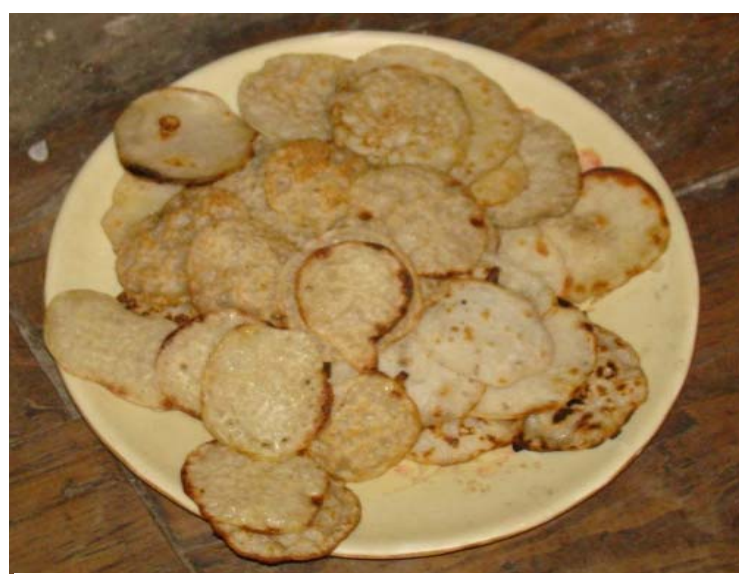

Ankelu, an ethnic food 
prepared from wheat flour batter are common in parts of Kangra, Bilaspur, Solan, Shimla and Mandi;

- Polle/ poltu, deep-fried unleavened bread is served as ceremonial food in Lahaul-Spiti, Kinnaur and parts of Shimla;

- Sepubadi, deep-fried preparation of black gram, cooked in yoghurt during the community feast in Mandi district;

- Kaale Channe ka Khatta, the sour curry of black gram, is prepared in Kangra, Mandi, Hamirpur and Solan and usually served with rice and madra during the community feast;

- Madra, curry of red kidney beans or gram cooked in yoghurt and clarified butter is one of the main item of community feast;

- Tchhoso roti, thick unleavened bread of kodo millets is occasionally served in Lahaul-Spiti;

- Patande/mande or pancakes of wheat or rice flour served as festive food in Sirmour, Solan and Shimla district. A scoop of smooth batter of wheat flour, milk and sweetening agent is cooked on griddle;

- Seera is the starch extract of wheat, prepared by soaking wheat, followed by grinding, and sun drying of its extract, which is later cooked in clarified butter as sweet pudding;

- Siddu, common in Shimla, Sirmour and Kullu are prepared by using wheat flour. The wheat dough is fermented and later its balls are filled with the stuffing of animal fat or lentil paste and steam cooked;

- Teliye mah, black gram cooked in clarified butter is served during the community lunch;

- Thukpa/Sung, a thick soup of peas and mixed grains is common in Kinnaur and Lahaul-Spiti;

- Tudkira Bhath, a traditional dish of Chamba is the combination of rice, lentils, potatoes and yoghurt along with onion, tomatoes, garlic, and spices;

Dhaam, a long-established, customary jovial feast of Himachal is prepared during the weddings, festivals and ritualistic performances. It is believed that the concept of dhaam originated more than one thousand years back in the valleys of Chamba, when the rulers of the reign directed the royal cooks to prepare special food as an offering to the deities. According to another belief, dhaam originated a long time, when the local rulers of Himachal were impressed with the hospitality of kings of Kashmir. They cooked a variety of foods and since then this tradition is continuing. The distinct features of dhaam are that the same is prepared on wood logs, the preparation starts a night before the feast and the food is served on pattal, the leaf plates. Dhunni or traditional smoked cooking is yet another feature of dhaam, where mustard oil is poured on a piece of red hot coal and kept in the preparation to impart smoky flavor. In traditional cooking, the use or onion and garlic are prohibited. The dhaam is prepared by the bhoti, the traditional chef, who usually belongs to Brahmin community and the art of cooking is inherited via a word of mouth. The food is cooked in special utensils made of brass or bronze, which are larger in size than the utensils used in routine. The main course consists of rice served with madra, khatta and metta. Though the ingredients of madra vary across districts, yet it is mainly prepared in clarified butter and yoghurt, for instance, madra of rajma (red kidney beans) and guchhi madra, (morels) is common in Chamba; madra of sepu badi in Mandi, madra of mash dal in Kullu, madra of ghandayali (Colocasia) and dhui dal (split black lentil) in Bilaspur, madra of safed chane in Kangra, etc. Subsequently, khatta is served, whose constituents vary, for instance, pumpkin, black gram and black-eyed pea. Tamarind, anardana (dried seeds of wild pomegranate) or dried mango powder along with jaggery are the main ingredients used for imparting sour taste. At times, dried dates and rai (brown mustard seeds) are added to impart special taste.

Mitta or sweet dish is served in the last, which has a variety across the districts. Madra of rajma, kale chane, kadhi, gucchi (morels) bhaat, khatta, and mitta bhaat (sweet rice) are the main items of Chambyali dhaam. Kangri Dham consists of telia mash, black lentil dal drenched in clarified butter mixed with spices, served with safed chane ka madra, kaale chane ka khatta and rice. Sepu badi, dhui dal, kaddu ka khatta, mash ki dal and kadhi served with rice are the specialties of Mandiyali dhaam. Badane ka mitta is yet another delicacy served in Mandiyali dhaam. Jhol, a traditional preparation of buttermilk is believed to act as appetizer is served in the last in Mandiyali dhaam.

The methods involved in cooking and serving have evolved over a period of time and form a part of traditional wisdom of people inhabiting in the region. Eating certain protein-rich foods such as $k a-$ sayatu chawal (local variety of rice), ogla/ phafara (buckwheat), gehu (wheat), makki (maize), koda (kodo millets), battu (chenopodium), rajmaa (red kidney beans), mash (black gram whole), jau (barley) and 
kulth dal (Horse gram), etc. is certainly beneficial. Another practice often found is the large intake of buttermilk/ curd rather than milk. The souring of milk has little effect on its nutritive value but to a large extent reduces the number of pathogenic organisms present. The traditional use of green leafy vegetables and wild plant/food is a beneficial practice. The green leafy vegetables are rich sources of carotene, ascorbic acid iron and calcium since these contain useful quantities of protein. Non-cultivated or wild edibles as well as cultivated ones are rich in vitamins, for example, chulli (wild apricot), dheu (Monkey fruit), galgal (Hill lemon), dahdu (wild pomegranate), etc. are rich in Vitamin C and hence their use must be promoted.

CONCLUSION. People still prefer using indigenous methods of cultivation, post-harvest management and food processing. Traditional grain preparation methods produce a more nutritious product than any machine milling. These methods are better and prevent the loss of nutrients. People in rural areas still use conventional methods of thrashing and grinding. Even today, there are gharats, the traditional watermills for grinding grains in some parts of the state. Among various methods involved for cooking of ethnic foods, some of techniques such as boiling and steaming are very good as they retain the nutrients content of food. Cooking of sprout legumes, which is common in some areas enhances the nutritive value of legumes as the soaking of whole-grain cereals before their processing into food or alcoholic beverage. Such practices not only help in providing nutrient rich food but are also contributing to good health. Thus, the ethnic foods and beverages are part of culture and reflect the prosperity and rich cultural heritage of the state.

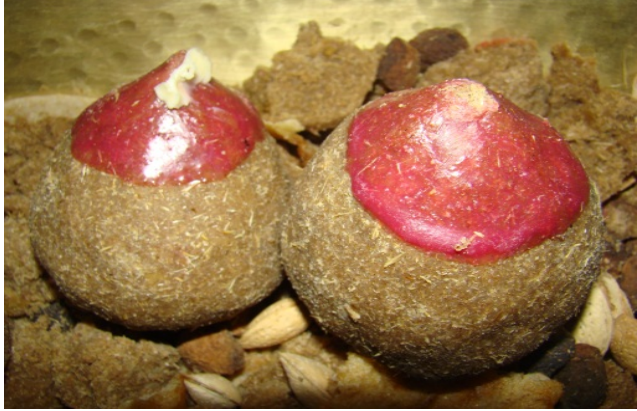

Barley Sattu

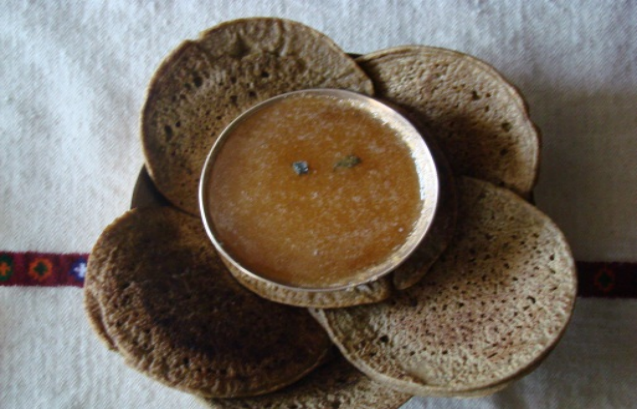

Hoda, the pancakes with honey

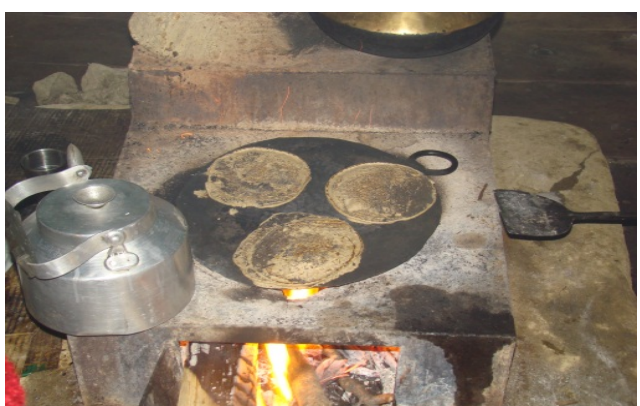

Preparation of Chiltu, the

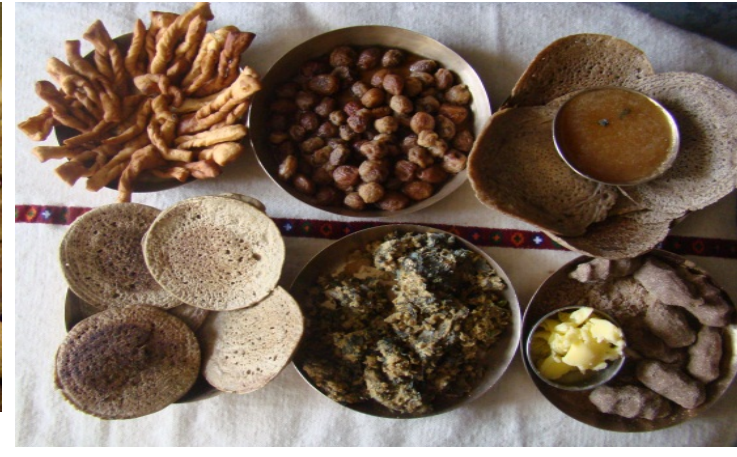

Ethnic food of Kinnaur

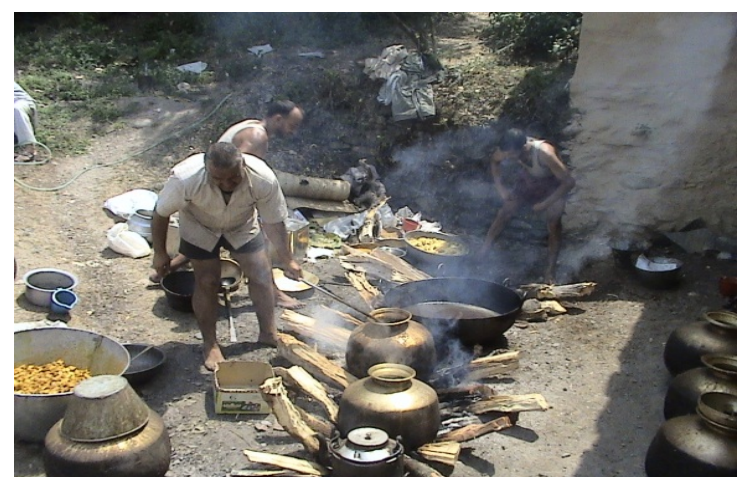

Bhoti, the traditional chef making

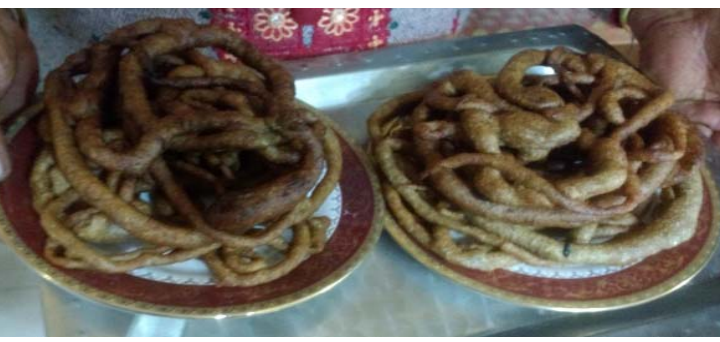

Jutthe, ethnic food 


\section{References $^{1}$}

1. McGee, H. Food and Cooking: An Encyclopedia of Kitchen Science, History and Culture. - London : Hodder \& Stoughton, 2004. - 896 p.

2. Jain, A. G. Analysis of Food Pairing in Regional Cuisines of India/A. Jain, N. K. Rakhi, G. Bagler // PLoS ONE. - 2015. - No. 10. - DOI: 10.1371/journal.pone.0139539/.

3. Navarrete, A. Energetics and the evolution of human brain size/A. Navarrete, C. P. V. Schaik, K. Isler // Nature. - 2011. - Is. 480. - Pp. 91-93.

4. Pollan, M. Cooked: A Natural History of Transformation. Penguin Books. - New York : Penguin Press, 2014. $-480 \mathrm{p}$.

5. Weber, S. Archaeo-botany at Farmana: new insights into Harappan plant use strategies / S. Weber, A. Kashyap, L. Mounce // Excavations at Farmana, District Rohtak, Haryana, India. - Kyoto : Nakanish Printing, 2011. - Pp. 808-823.

6. Sherman, P. W. Darwinian Gastronomy: Why we use spices. Spices taste good because they are good for us / P. W. Sherman, J. Billing // Bioscience. - 1999. - Is. 49. - Pp. 453-463.

7. Long, L. M. Culinary Tourism: A Folkloristic Perspective on Eating and Otherness // Southern Folklore. - 1998. - Is. 55. - Pp. 181-204.

8. Mead, M. Culture change in relation to nutrition. - [...] : Burgess \& Lane, 1962. - Pp. 50-62.

УДК 379.8:343.81(571.150-25)

DOI 10.32340/2414-9101-2020-2-17-22

И. Н. Зуев,
Алтайский государственный университет (Барнаул, Россия)

Э. А. Чеглаков,

Вечерняя (сменная) общеобразовательная школа № 2 (с. Шипуново Алтайского края, Россия) izuev81@gmail.com

\section{ФОРМИРОВАНИЕ СОЦИОКУЛЬТУРНОЙ СРЕДЫ В ИСПРАВИТЕЛЬНЫХ УЧРЕЖДЕНИЯХ}

Аннотация. Проанализированы некоторые административные, социальнопсихологические, иные барьеры, препятствующие формированию социокультурной среды, благоприятной для успешной ресоциализации заключённых, в условиях современных отечественных учреждений уголовно-исправительной системы. Аргументирована необходимость постановки акцента в практике социально-педагогической работы с правонарушителями, отбывающими наказание в местах лишения свободы, на их последующую активную ресоциализацию средствами любительского театрального творчества, обладающего значительным воспитательным потенциалом. Изложена обзорная характеристика опыта работы зарубежных (Западная Европа, США) пенитенциарных учреждений в области содействия ресоциализации заключённых. На примере работы Лечебно-исправительного учреждения № 1 Управления Федеральной службы исполнения наказаний по Алтайскому краю (г. Барнаул, Россия) рассмотрены базовые условия для формирования и закрепления психологических установок у осуждённых на социальную адаптацию.

Ключевые слова: сочиокультурная среда, российские исправительные учреждения, российские лечебно-исправительные учреждения, клуб, любительский театральный коллектив, икола, социализация личности, социокультурные факторы социализации личности, ресоциализация заключённых, проблемы сочиальной адаптачии бывших осуждённых клишению свободы.

Понятие «социокультурная среда» часто употребляется в современной научной литературе. Но в разных областях научного знания семантические оттенки этого понятия разнятся. Традици-

\footnotetext{
${ }^{1}$ Рус.: список литературы.
} 